\title{
Household's Willingness to Pay for Drinking Water Quality Service Improvement in Damaturu, Nigeria
}

\author{
MOHD RUSLIYACOB ${ }^{1}$, SULEIMAN ALHAJI DAUDA ${ }^{2}$, \\ ALIAS RADAM $^{2}$ and ZAITON SAMDIN ${ }^{3}$
}

${ }^{1}$ Faculty of Environmental Studies, University Putra Malaysia, 43400 UPM Serdang, (Selangor). ${ }^{2}$ Faculty of Economics and Management, University Putra Malaysia, 43400 UPM Serdang, (Selangor). ${ }^{3}$ Faculty of Forestry, Universiti Putra Malaysia, 43400 UPM Serdang,(Selangor).

http://dx.doi.org/10.12944/CWE.8.3.06

(Received: August 05, 2013; Accepted: September 24, 2013)

\begin{abstract}
Human existence depends largely on availability of water both in high quality and sustainable supply. Improved quality drinking water has the ability to improve our standard of living, reduces mortality rates and morbidity associated with water born diseases. Damaturu have witnessed unprecedented increase and influx of population due to its new status by been made the capital of Yobe State in 1991, provision of safe drinking water thus became a matter of serious concern and this led to prevalence of water borne diseases like diarrhea and other gastro intestinal disorder. Yobe State has embarked on the construction of "Damaturu regional water supply project" which promises $100 \%$ access to portable water to Damaturu. The general objective of the study is to assess the household's willingness to pay for an improved quality drinking water. Choice experiment approach was used, and four attributes of drinking water quality were identified namely; tap water quality (TWQ), Tap water supply (TWS) tap water pressure (TWP) and Price. Conditional logit model (CLM), involving randomized sampling of 300 respondents was carried out. The results were found that respondents with higher level of education are more willing to pay. Identifying the mix of attributes and their prices based on respondents' drinking water quality demand preferences would help policy makers to know and provides the households with a preferred and affordable drinking water and also facilitates effective tariff structure for cost recovery and sustainability.
\end{abstract}

Key words: Choice Experiment, Water Quality, Household Preference, Choice Modeling, Willingness to Pay, Conditional Logit Model.

\section{INTRODUCTION}

Water is fundamental human need; human life and existence of all eco system depends largely on the availability of water both in high quality and sustainable quantity supply, safe water is the water delivered to the consumers that can be used directly for drinking, cooking, and washing. It is the responsibility of authority at all levels to review, inspect, monitor and evaluate on continues basis the water supplied to the community, using constantly updated water standard John (1990). Tap water in most of the developing countries is unsafe for direct drinking and the supply services are commonly unreliable Vasquez et al., (2009). Damaturu like most of the municipalities in Nigeria, tap water quality and sustainable supply services remained a matter of serious concern to the authorities, because government capacity to provides the growing population with the safe drinking water is not commensurate with the population growth, household's are left to cater for their sources of water as such a lot of valuable time and limited resources are been inefficiently 
allocated towards sourcing for and improving the quality of drinking water.

Damaturu in Nigeria, like other cities in developing countries, the tap water quality is still remaining unsafe and harmful for direct household consumption. The common problem in society on high mortality rates and morbidity is on increase as a result of water borne diseases such as cholera, diarrhea and other gastro intestinal diseases (Emeka et al., 2008, Oruanye et al,. 2010 and Akinsola et al,. 2007). Improvements in the water quality supplied by the municipalities would result in higher cost of such services which would have to be borne by the users and acceptability of any additional charges should be investigated Genius et al., (2008). Thus the rationale for this study is to assess the household's preferences for varying attributes of water quality and estimates their willingness to pay for drinking water quality improvement. This paper is organized into five sections. Section one is the introduction, followed by section two which describes the location of study. Section three explains the methodology and sources of data used in study. The empirical results are presented in section four, while the last section offers some discussion and concluding comments with regard to drinking water service improvement.

\section{Study area}

Damaturu town is the capital of Yobe State and the local government headquarters of Damaturu. It is located between longitude110 44' 40 " $N$ and latitude $11057^{\prime} 40^{\prime \prime} \mathrm{E}$ in the north eastern part of Nigeria, it has total area of about $400 \mathrm{~km}^{2}$. However, the main urban area of Damaturu occupies only an area of about $20 \mathrm{~km}^{2}$ (Babalola et al., 2010). Damaturu has no industrial establishment; it is dominated by agrarian economy that produces mainly beans, millet, groundnut, gum Arabic, cotton etc. Damaturu town rose from obscure local government area to the status of state capital in 1991, when Yobe State was created out of Borno State. These sudden change in status brought about an increase in the population from less than ten thousand $(10,000)$ persons before 1991, to a population of about two hundred and twenty five thousand eight hundred and ninety five $(225,895)$ population in 2011, Babalola et al., (2011).
Damaturu is not drain by any river it is a water deficit region, the rainfall ranges between $400 \mathrm{~mm}$ to $800 \mathrm{~mm}$ with an annual mean of $750 \mathrm{~mm}$ with very low surface water during rainy season, hence absence of surface water resources. The town main sources of drinking water are from underground water resources which are usually accessed through drilling of boreholes and artesian wells Emeka et al., (2008). Water supply to Damaturu has been grossly inadequate because of the expanding population and increase in commercial activities. At present the total water supply is about $10,000 \mathrm{~m}^{2} /$ day extracted from 29 production wells and the discharge of each well ranges from 80 to $325 \mathrm{~m}^{2} /$ day. The projected demand of water to Damaturu presently is over $89,120 \mathrm{~m}^{2} /$ day Mohamed et al., (2008). This problem must be addressed with a quantitative approach rather than a qualitative approach alone. Yobe state government has embarked on the construction of a Water project in Damaturu named; "Damaturu region water supply project" which was targeted upon completion to provide $100 \%$ rate of access to improved quality drinking water to the Damaturu metropolitan. Presently the main source of water supply is groundwater wells within taps in $10-15 \%$. However, recent report by the State government indicated that $45 \%$ of residential houses in Damaturu are being connected to Yobe State Water Corporation services.

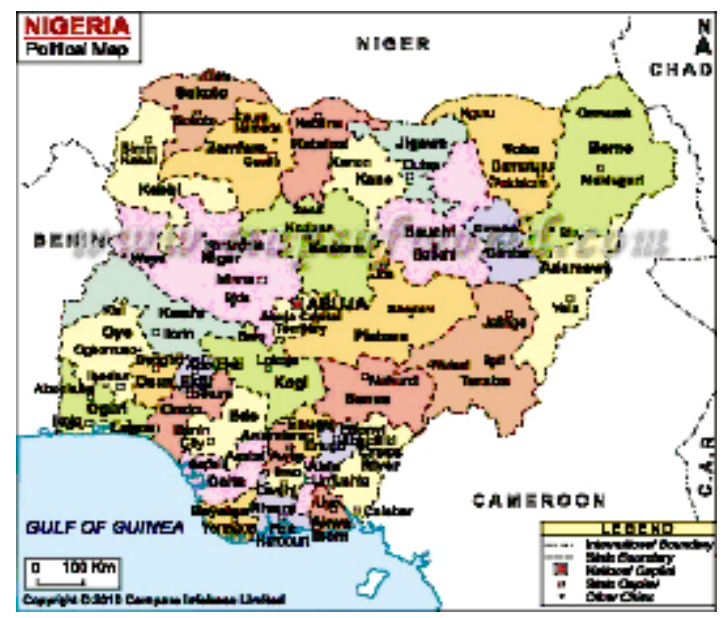

Fig .1(a): Political map of Nigeria, showing Yobe state top left. www.mapsofworld.com 


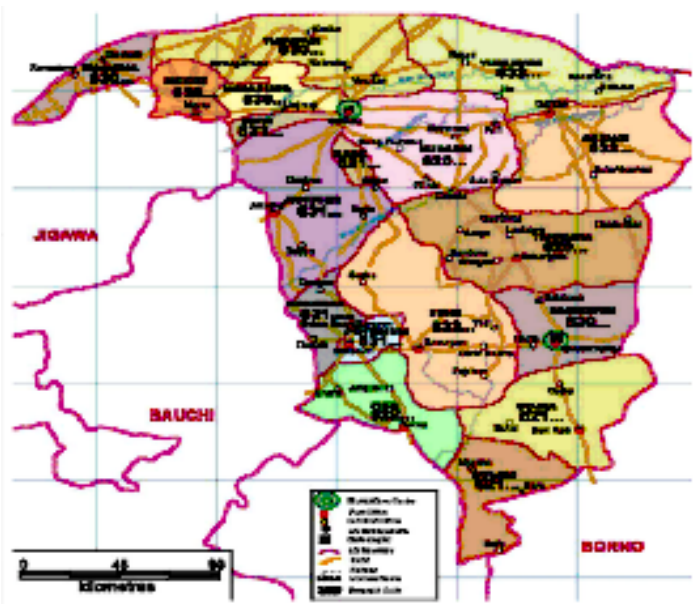

Fig .1(b): Political Map of Yobe state showing Damaturu, the study area with postal code number 620 .

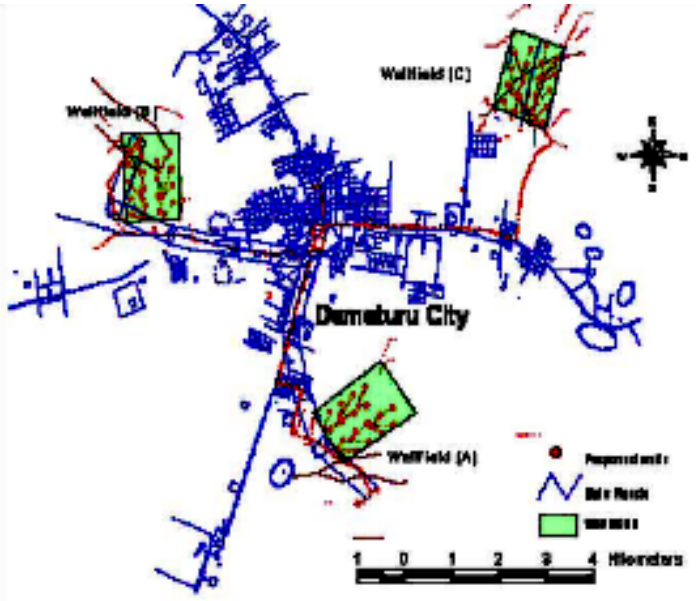

Fig.1(c): Map of Damaturu metropolitan showing the position of the proposed wellfields $A, B$ and $C$ for the proposed Damaturu region water supply project

Table 1: Drinking Water Attributes and Levels

\begin{tabular}{|c|c|c|}
\hline Attributes & Levels & Descriptions \\
\hline Tap water Quality (TWQ) & & Tap water quality refers to the drinking water with \\
\hline TWQ1 & Non Satisfactory & high quality; safe for direct human consumption, \\
\hline TWQ2 & Satisfactory & ideally it should be colorless, \\
\hline TWQ3 & Very Good & $\begin{array}{l}\text { tasteless, odorless and compatible with } \\
\text { standard of drinking water quality. }\end{array}$ \\
\hline Total Supply of Water (TSW) & & This refers to the total supply of water to the \\
\hline TSW 1 & Regular & households from the Yobe State Water Corporation \\
\hline TSW 2 & Irregular & measured in terms of rate supply of water to \\
\hline TSW 3 & Very Irregular & the household. \\
\hline Tap Water Pressure (TWP) & & Tap water pressure refers to the pressure with \\
\hline TWP 1 & Low & which Moderate the water gushes out from the tap, \\
\hline TWP 2 & Medium & so as to reduce Low wasting of time. \\
\hline TWP 3 & High & \\
\hline Water Bill Price $(P)$ & $\begin{array}{l}\text { N200 } \\
\text { N250 } \\
\text { N300 } \\
\text { N400 }\end{array}$ & $\begin{array}{l}\text { Water bill refers to household monthly water bills } \\
\text { charged by Yobe state Water corporation, presented } \\
\text { as amount increase over the current bill. }\end{array}$ \\
\hline
\end{tabular}

Note: Italics present the status quo attribute levels

\section{METHODOLOGY}

\section{Sampling Procedure and Survey Design}

The survey was carried out between June and August 2011 involving a random sample of
300 household in Damaturu metropolitan. The task of the interview was carried out by five trained enumerators to conduct a face to face interview. At the beginning of each interview session, respondents were told that they have been randomly selected for survey with the purpose of 
assessing their willingness to pay for drinking water quality improvement. At the beginning of each interview session, respondents were informed about the purpose of their been randomly selected for the survey aiming at assessing their willingness to pay for their drinking water quality improvement and their participation would help to improve policy making.

Choice Experiment (CE) method is consistent with Random Utility Model (RUM). For the fact that individuals are assumed to choose the alternatives which maximizes their utility, we can apply probabilistic models to choose between the different alternatives available in each choice set; therefore a good is valued in terms of its attributes. In each choice set attribute representing three alternative management options include a status quo option. A status quo was often included to account for forced choice, Hensher et al., (2005) likewise in all the choice sets prices were introduced and thus, willingness to pay estimates for changes in attributes levels can be derived from marginal utility estimates Poirer et al,. (2010).

Bateman et al., (2002) mentioned that choice experiment involves of five important stages namely: selecting attributes, determining levels, choosing experimental design, constructing choice sets and measuring preference. Attributes for water quality improvement was determined following consultation of relevant literatures and the discussion with focus group which was found to be related to tap water. The concept of tap water quality, supply and pressure were adopted and percentage increase over the current water bill stood for the price.

The questionnaire consisted mainly of four parts: choice experiment questions, attitudinal questions, perception question, and sociodemographic questions respectively.

The choice experiment part was presented to the respondents with six choice sets which consist of two management option usually with status quo or opt out option, each with price as the percentage increase over the current bills charged by the Yobe State Water Corporation, taken at an average of N200 at flat rate charges. Status quo option implies no improvement and no additional cost, it has been included to avoid 'forced choice'. The respondents faces six choice sets and for each set there are three options in which they were ask to choose any one, with each alternative having various bundles of attributes and at various prices, attributes and their level as presented in Table 1.

\section{Model specification}

Conditional logit is one of the methods in discrete choice analysis. If respondent " $n$ ", is faced with a choice among "j" alternatives in a choice set, the attributes in the choice sets may either be in qualitative or quantitative term of alternative "i" in the choice set as faced by the respondent $n$ as the vector $X_{\text {in }}$. The probability $\left(P_{\text {in }}\right)$ that respondent " $n$ " chooses alternative " $i$ " in the choice set as faced by the respondent depends on the attributes of alternative " $i$ " compared with other alternatives (i.e $X$ in relative to all $X j n ; j \neq I)$. In this case, there are three alternatives: management option 1, 2 and status quo and the probability can be presented by a parametric function of general form as follows:

$$
P_{i n}=f\left(X_{i n}, X_{j} n ; j \neq I, \beta\right)
$$

Where;

$P_{\text {in }}=$ probability of respondent $\mathrm{n}$ choosing alternative $i$.

$X_{i n}=\mathrm{a}$ vector of observable characteristics of alternative $i$ accessible to respondent $n$.

$X j n=$ a vector of observable characteristics of alternative $j$ accessible to respondent $n$.

In this case, $f$ is the function that relates the observed data with the choice probabilities. This function is specified up to some vector of taste parameter $\beta$ to be estimated. These parameters can be interpreted by estimating the marginal value of the each water attributes in the respondent's choice set, Mohd Rusli et al., (2008). The estimation of the Random Utility Model would be obtained when we specify the distribution on the error term, and to develop the conditional logit model, by McFadden (1974) and Train (2003). It was assumed that all the error term in the choice set are 
independently and identically Distributed IID with all Weibull distribution, the conditional logit model can be developed. Thus, the probability of household $\mathrm{n}$ choosing alternative i can be specified as follows:

$$
P i n=\frac{\exp (\mu V i n)}{\sum j \exp \left(\mu X_{j} n\right)}
$$

By assuming that Vin is linear in parameters, the functional form of the respondents' systematic component of utility function can be expressed as:

$$
V i n=\beta 1 X n+\beta 2 X m+\ldots \beta k X k m
$$

Where $X s$ are variables and $\beta$ s are coefficients to be estimated. If a single vector of coefficient $\beta$ that applies to all the utility functions associated with all the alternatives is defined and the parameter $\mu=1$, Train ( 2003) Swait and Louviere (1993) the equation (3) can then be rewritten as:

$$
P i n=\frac{\exp \left(\beta^{\prime} V_{i} n\right)}{\sum j \exp \left(\beta^{\prime} V^{\prime} n\right)}
$$

Where;

Pin = respondent $\mathrm{n}$ choice probability of alternative $i$.

$X_{i} n$ and $X_{j} n=$ vector describing the attributes of $i$ and $j$.

$$
\beta=\text { vector of coefficient }
$$

Then, the next step is to estimate the choice probability and to calculate the welfare measure. The ratio of an attribute's coefficient and the price coefficient represents the marginal implicit price of the attributes. This ratio represents the implied change in the implicit price of the attributes relative to a current situation as in the equation below:

$$
\begin{aligned}
\rho i, k= & \partial \mathrm{V} / \partial \mathrm{Xi}, \mathrm{k}=-1 \beta \mathrm{i}, \mathrm{k} \\
& \partial \mathrm{V} / \partial P \mathrm{i}, \mathrm{k} \beta \mathrm{i}, \mathrm{k}=\mathrm{p}
\end{aligned}
$$

\section{RESULTS AND DISCUSSION}

\section{Demographic and Socio-economic Characteristics}

A result of the respondent demographic profile is presented in Table 2. Ages of the respondent's ranges from 23 to 70 year olds with the mean age of 41 year olds. Male are majority which represent $96.7 \%$ from the total samples. In terms of respondent educational background, the result found that illiterates $(9.0 \%)$, primary school (13.0\%), university level (18.0\%), secondary school $65(21.7 \%)$ and polytechnic /college 115 (38.3\%) having the highest number of attendants respectively.

Respondent employment indicates that those employed at the formal sector constituted $82.3 \%$, unemployed respondents are $5.7 \%$ of the total respondents, women who engages in home duties are only $3.0 \%$, retired personnel constituted $4.3 \%$, and those employed in informal sector or self employed constitutes $4.7 \%$. Meanwhile, total number of the people living in the household two people representing $12.3 \%$ of the total respondents, to the highest which has from six people and above which is 96 households which constituted $32 \%$ of the total respondents.

Gross monthly household income indicates that households earning below N16,000 are low income earners and they represents the smallest number 21 respondents which represents only $7 \%$. The middle income earners are those earning between N16,001 to N34,000 they represent the largest percentage of $73.0 \%$ and $20.0 \%$ contributed by respondents with high income earners of their gross monthly household income is above $\mathrm{N} 34,000$.

\section{The Choice Experiment}

Table 3 shows the empirical results of choice experiments (CE) for the drinking water quality service improvement in Damanturu Nigeria. The $C L$ results are presented for the simple model (Model 1) and interaction model (Model 2) of water quality services attributes. In CL simple model, however, it was found that the coefficient TWP3 is 
Table 2 : Socio-Demographic profiles of respondents $(\mathrm{N}=\mathbf{3 0 0})$

\begin{tabular}{lll}
\hline Variables & Definitions and Coding & Freq (\%) \\
\hline AGE & Age in years (mean) & 41.88 \\
GEN & Gender (1; male 0; female) & \\
& Male & $290(96.7)$ \\
EDU & Female & $10(3.3)$ \\
& Education level & \\
& Illiterate & $27(0.9)$ \\
& Primary school & $39(13)$ \\
& Secondary school & $65(21.7)$ \\
& Polytechnic/College & $115(38.3)$ \\
EMP & University & $54(18)$ \\
& Employment ((1; employed 0; others) & \\
& Employed & $247(82.3)$ \\
& Unemployed & $17(5.7)$ \\
& Home duties & $9(3.0)$ \\
& Retired & $13(4.3)$ \\
HHOLD & Others & $14(4.7)$ \\
& Household Number (mean) & 4.33 \\
& 2 persons & $37(12.3)$ \\
& 3 persons & $58(19.3)$ \\
& 4 persons & $70(23.3)$ \\
& 5 persons & $39(13.0)$ \\
& 6 persons \& above & $96(32.1)$ \\
HINC & Monthly gross household income (N) & \\
& Less than N16,000 & $21(7.0)$ \\
& N16,001-N34,000 & $219(73.0)$ \\
& More than N34,000 & $60(20.0)$ \\
\hline
\end{tabular}

not significant. This is because the TWP3 level is to higher related to base level, hence, less favored by respondents. This is a possible explanation why it may have occurred. Meanwhile, all coefficients for attribute levels TWQ2, TWQ3, TWP2, TWS1, TWS2 and Price attribute levels are significant at the 1\% level. The overall coefficients for the attributes levels (except Price) are positive, indicating that the chosen base level has the smallest contribution to utility.

In such exercise, there are possibilities of improving model fit and examining where the sources of the inaccuracies may be occurring. First, it can be improved by the inclusion of socioeconomic factors and respondent visits at characteristic attributes in order to account for heterogeneity of preferences. The respondents' socio-economic information included age, gender, education levels, occupation, income, place of origin and membership of environmental group. Second, the socio-economic variables can be interacted with main attributes and can be used in order to avoid the singularities problem. These interactions help to generate a rich data set about the specific influences of choice on each level used in the model. However, in interaction model, the log-likelihood ratio value has a small rise from the simple model, indicating that a model specification has been small improved. Improvements in the model are also evidenced by the increase in the Pseudo-R2 statistic from 0.135 to 0.142 .

However, in a comparison of the $\mathrm{CL}$ interaction model with the $\mathrm{CL}$ simple model, it can be seen that variables TWS1 and TWP1 have 
YACOB et al., Curr. World Environ., Vol. 8(3), 381-389 (2013)

Table 3 : Results for Conditional Logit Model

\begin{tabular}{|c|c|c|}
\hline \multirow[t]{2}{*}{ Variable } & \multicolumn{2}{|c|}{ Conditional Logit } \\
\hline & $\begin{array}{c}\text { Model 1 } \\
\text { Simple Model } \\
\text { Coefficient }(\beta)\end{array}$ & $\begin{array}{c}\text { Model } 2 \\
\text { Interaction Model } \\
\text { Coefficient }(\beta)\end{array}$ \\
\hline TWQ2 & $\begin{array}{c}1.5831^{* * *} \\
(0.1387)\end{array}$ & $\begin{array}{c}0.9689^{* * *} \\
(0.2414)\end{array}$ \\
\hline TWQ3 & $\begin{array}{c}1.8832^{* * *} \\
(0.1683)\end{array}$ & $\begin{array}{c}1.1125^{* * *} \\
(0.2690)\end{array}$ \\
\hline TWS1 & $\begin{array}{c}0.2521)^{\star \star *} \\
(0.1154)\end{array}$ & $\begin{array}{l}0.2627^{\star \star} \\
(0.1158)\end{array}$ \\
\hline TWS2 & $\begin{array}{l}1.4654^{* * *} \\
(0.1527)\end{array}$ & $\begin{array}{c}1.4826^{* * *} \\
(0.1532)\end{array}$ \\
\hline TWP1 & $\begin{array}{c}0.7334 \\
(0.2744)\end{array}$ & $\begin{array}{c}2.2845^{\star \star *} \\
(0.8639)\end{array}$ \\
\hline TWP3 & $\begin{array}{c}1.1732^{* * *} \\
(0.3154)\end{array}$ & $\begin{array}{c}2.5235^{* * *} \\
(0.7366)\end{array}$ \\
\hline PRICE & $\begin{array}{c}-0.8574^{* * *} \\
(0.1849)\end{array}$ & $\begin{array}{c}-0.8799^{* * *} \\
(0.1855)\end{array}$ \\
\hline TWQ2_EDU & & $\begin{array}{c}0.3594^{\star * \star} \\
(0.1156)\end{array}$ \\
\hline TWQ3_EDU & & $\begin{array}{c}0.4509^{* * *} \\
(0.1241)\end{array}$ \\
\hline TWP1_GEN & & $\begin{array}{c}-2.3390^{* * *} \\
(0.8811)\end{array}$ \\
\hline TWP3_GEN & & $\begin{array}{c}-1.4497^{* * *} \\
(0.7321)\end{array}$ \\
\hline N (Observations) & 1500 & 1500 \\
\hline Log likelihood & -1424.751 & -1412.831 \\
\hline $\mathrm{R}^{2}$ & 0.135 & 0.1426 \\
\hline Adjusted $\mathrm{R}^{2}$ & 0.133 & 0.1395 \\
\hline
\end{tabular}

Note: Standard errors in parentheses

* Significance at $10 \%$ level, ${ }^{* *}$ significance at $5 \%$ level and ${ }^{* *}$ significance at $1 \%$ level

Table. 4: Marginal Rate of Substitution (\%) for Drinking Water Quality Improvement

\begin{tabular}{|c|c|c|}
\hline Variable & $\begin{array}{l}\text { CL Simple } \\
\text { Model (\%) }\end{array}$ & $\begin{array}{c}\text { CL Interaction } \\
\text { Model(\%) }\end{array}$ \\
\hline TWQ2 & $184.63^{\star \star \star}$ & $110.11^{* * *}$ \\
\hline TWQ3 & $219.63^{* * *}$ & $126.43^{* * *}$ \\
\hline TWS1 & $29.40^{\star *}$ & $29.86^{* *}$ \\
\hline TWS2 & $170.91^{* * *}$ & $168.49^{* * *}$ \\
\hline TWP1 & 8.55 & $259.61^{* *}$ \\
\hline TWP3 & $136.83^{* * *}$ & $286.77^{\star * *}$ \\
\hline
\end{tabular}

changed; an estimated coefficient TWS1 which significant at $1 \%$ in simple model reduce to $5 \%$ significant level and TWP1 tends to be significant at $1 \%$. This indicates that there are strong relationships affected by the interaction variables to primary attributes. The variables of TWQ2_EDU and TW3_EDU were significance and indicates that a higher level of education contributes positively to support the drinking water quality improvement. The contribution gender variable (GEN_TWP1 and GEN_TWP3) towards drinking water pressure were more preferred. 
The payment vehicle for drinking water quality service improvement simply uses an increase in water billing price, measured as a percentage (\%). The household is required to trade off how many percent (\%) he or she is willing to pay as an increase in the water price they pay to obtain and enjoy a varying mix of water service attributes. The attributes for the water billing price (PRICE). Thus, the marginal values can be calculated from the marginal rate of substitution between an attribute coefficient and the coefficient for the price parameter. MRS are estimated and reported in Table 4. The marginal rate of substitution of the tap water attributes for each level and it was translated as percentage increase over the current water bill that the households are willing to pay for the improvement in their water quality attributes, TWQ2 and TWQ3 have a marginal values of $185 \%$ and $220 \%$ as a percentage increase over the current water bills respectively, TWS1 and TWS2 have the marginal values of $29 \%$ and $171 \%$ as a percentage increase over the current water bills respectively, similarly, TWP1 and TWP3 are having a value $8 \%$ and $137 \%$ percentage increase over the current water bills respectively. With the exception of TWP1 all the parameter level are statistically significant at least at $10 \%$ level, this explains the fact that household are not willing to pay more for any water pressure level below the status quo at TWP2.

The marginal rates of substitution between the tap water attributes for each level and for the interacting variables it is been presented as a percentage increase over the current water bills which households are willing to pay for their drinking water quality improvements. TWQ2 and
TWQ3 have marginal values standing at $110 \%$ and $126 \%$ and TWS1 and TWS2 have marginal value equivalent to $30 \%$ and $168 \%$ increase over the current water bills, TWP1 and TWP3 stood at amazingly high values of $259 \%$ and $286 \%$ increases over the current water bill respectively.

Inclusion of socio-demographic characteristics of households to the simple model was justified to take care of the heterogeneity in the preferences of the householdswere interacted with the main attributes (TWQ2_EDU, TWQ3_EDU, TWP1_GEN and TWP3_GEN). The result of the model that interacted with the main attributes have improves the model fit, there is an improvement in the log likelihood of the interaction model. This implies water quality attributes and levels included in the model with interactions have avails the households with more choice options than the simple models.

\section{CONCLUSION}

The result of this study which to the authors' knowledge is the first of its kind in the study area proves the willingness of households in Damaturu to pay more than what they have been paying in order to get improved quality drinking water. Similar to finding by Whittington et al., (1991) in Onitsha Nigeria where households are paying more than the authorized tariff to get safe drinking water from other sources. Provision of safe drinking water will be a timely intervention by the government towards poverty and health related diseases reduction which will eventually improve the living standard of people in Damaturu.

\section{REFERENCES}

1. Akinsola. R.O, Garba. B.M.I. and Godowoli.I Bacteriological analysis of bore-hole water in Federal Polytechnic Damaturu. Chemclass journal. pp214-217 (2007).

2. Babalola., A. Tsenbeya., H. Busu., I. and Majid., M.R. Practice and Challenges of solid waste Management in Damaturu, Yobe State, Nigeria. Journal of Environmental Protection December 2010, http://www.sci Rp.org/journal/jep (2010).
3. Babalola. A and Busu. I, Selection of landfield sites for solid waste treatment in Damaturu town using GIS technique. Journal of environmental protection 2, 1-10 (2011).

4. http://www.Scr Rp.org/journal/jep.

5. Bateman, I.J., Carson., R.T., Day, B., Hanemann, M.,N., Hett, T., Jones-Lee, M., Loomes, G., Maurato, S., æzdemiroglu, E., Pearce, D. W., Sugden, R., and Swanson, J., Economic Valuation with stated Preference 
Techniques: A Manual, Cheltenham: Elgar (2002).

6. Casey J.F, Kahn J.R, and Rivas. A. Willingness to pay for improve water Service in Manaus, Journal of Ecological Economics 58, 65-372 (2006).

7. Cholera death toll rises to 352. Tribune Newspaper 26th August. www.tribune.com.ng/index ...10239-choleradeath-toll-rises-to-352 (2010).

8. Damaturu Yobe State: (www.nipost gov.ng/ post) map viewed on 28/12/2011

9. Dawoud., M.A and Raouf., A.R.A : Groundwater Exploration and Assessment in Rural Communities of Yobe State, Northern Nigeria. Water Resources management, 23:3, 581-601 (2010). Dol:10.1007/s11269-008-9289-x

10. Emeka., D.O and Weltime., O.M : The Trace of Elements Determinations in Municipal Water Supply in Damaturu Metropolis, Yobe State, Nigeria. Bayero Journal of Pure and Applied Sciences, 1:1 (2008).

11. Genius. M, Hatzaki.E, Kouromichelaki.E.M, Kouvakis.S, Nikiforaki.S, Tsagaraki.K.P, Evaluating consumers' willingness to pay for improved portable water quality and quantity, Water resources management 22: 18251834 (2008).

12. Hala, A.A, and Carlsson, F. Evaluating the Welfare Effect of Improved Quality Water Using Choice Experiment Method. Department of Economics, Gothenburg University, Working Paper in Economics Number. 131 (2004).

13. Hensher. D, Shore.N and Train.K Households' willingness to pay for water services attributes. Environmental \& resource economics 32: 509-531 (2005).

14. John D Zuane P.E, Hand book of Drinking water quality. John Willey and Sons, Inc. USA
(1996).

15. Louviere,J.J, Hensher,D.A, Swait.J.D, and Adamowicz,W. Stated choice methods:Analysis and applications. Cambridge, United Kingdom, Cambridge University Press (2001).

16. Map of Nigeria, www.mapsofworld.com viewed on 22/12/2011s

17. Mc Fadden, D. Conditional Logit analysis of Qualitative Choice Behavior: Frontier in Economics: 15: 447-470 (1974).

18. Mitchell R.C and Carson, USA.Using survey to value public goods. Washington DC (1989).

19. Oruonye., E.D and Medjor., W.O. Microbial analysis of Municipal Water Supply in Damaturu, Yobe State, Nigeria. Nigerian Journal of Microbiology. 24(1): 2106-2109 (2010).

20. Poirier. J and Fleuret. A, Using a choice experiment method for valuing improvement in water quality: a simultaneous application for four recreation site of river basin. Viewed on 10/4/2012. Congress.afse.fr/docs/2010/ 920347papiermultiside.pdf (2010).

21. Train, K.E, Discrete choice method with simulation. Cambridge, United Kingdom Cambridge University Press (2003).

22. Mohd Rusli, Y., Alias, R., and Shuib, A. Economic Valuation of Marine Park Ecotourism Malaysia: The case of Redang Island Marine Park. Universiti Putra Malaysia Press (2008).

23. Yobe State government of Nigeria, Final water supply and sanitation policy, Yobe printing corporation, pp 22 (2010).

24. Whittington. D, Lauria. D, T and Xinming Mu: A study of water vending and willingness to pay for water in Onitsha, Nigeria. World Development 19: 2/3, pp. 179-198. Great Britain (1991). 